\title{
A Misdiagnosis of a Breast Tumor: Histology Solves It
}

\section{Um Diagnóstico Presuntivo de Neoplasia da Mama: A Histologia Resolve}

Nádia Silva ${ }^{1 \# ~, ~ J o a ̃ o ~ V a s c o ~ B a r r e i r a ², ~ S u s a n a ~ N u n e s ~}{ }^{1}$, Inês Morujão ${ }^{1}$, Ana Correia ${ }^{1}$

\begin{abstract}
A breast lump can be benign or malignant, the late one can be primary or metastatic. When the primary neoplasm is unknown the diagnosis, management and treatment maybe quite difficult. We present a case of stage IV gastric cancer, where the first complaint was a breast lump. The rare incidence of such clinical presentation justifies reporting this case and highlights the importance of multidisciplinary teams in the management of cancer patients.

KEYWORDS: Breast Neoplasms/diagnosis; Breast Neoplasms/pathology; Breast Neoplasms/secondary; Histology; Neoplasms, Unknown Primary
\end{abstract}

\section{RESUMO}

O nódulo mamário pode ser benigno ou maligno, sendo que este último pode ser primário da mama ou metastático. Quando a neoplasia primária é desconhecida, o diagnóstico e orientação terapêutica podem ser bastante difíceis.

Apresentamos o caso de uma doente com cancro gástrico, estadio IV, em que a primeira apresentação foi um nódulo da mama. A incidência rara de tal apresentação clínica justifica o relato deste caso e destaca a importância de existência de equipas multidisciplinares na abordagem do doente oncológico.

PALAVRAS-CHAVE: Histologia; Neoplasias da Mama/diagnóstico; Neoplasias da Mama/patologia; Neoplasias da Mama/secundário; Neoplasias Primárias Desconhecidas 


\section{INTRODUCTION}

Despite advances in screening, diagnosis and treatment, breast cancer is still the leading cause of cancer associated mortality among females worldwide. Breast metastasis from other neoplasm are rare, accounting for 0.5\% - $2 \%$ of all mammary malignancies. The primary causes of breast metastasis are from melanoma, lymphoma, lung cancer, ovarian carcinoma, sarcoma, gastrointestinal and genitourinary tumor. ${ }^{1}$

Gastric carcinoma is the fourth most prevalent cause of cancer in Europe and the fifth cause of death by cancer in Portugal. ${ }^{2}$ Peritoneum, liver, lymph nodes and lungs are the most common sites of distant metastasis of gastric cancer. Therefore, breast is a rare site for distant metastasis.

Normally a similar immunohistochemical characteristic is found between the primary tumor and the breast biopsy, which helps to determine the primary tumor origin. Because of only sporadic cases and small series of patients reported, little is known of specific treatment and prognostic in these patients.

\section{CASE REPORT}

The authors describe a case with unusual presentation in a peculiar clinical context. We present a case of a 54 years-old female patient, with a past history of breast cancer, July 2003. She had an invasive carcinoma of the right breast, staged as pT4N2MO, G2, ER +, PR +, HER2 and was submitted to a radical modified mastectomy. She undergone 6 cycles of chemotherapy [cyclophosphamide $600 \mathrm{mg} / \mathrm{m}^{2}$ and docetaxel $75 \mathrm{mg} / \mathrm{m}^{2}$, intravenous, every 3 weeks with no adverse effects grade 3 or 4], 2 years of ovarian suppression and chest wall and axillar radiotherapy. After ending chemotherapy, the patient started hormone therapy with an aromatase inhibitor, letrozole $2.5 \mathrm{mg}$, for 10 years, until 2013 and maintained the follow-up with her Family Doctor.

In January 2019, because of a new left breast lump she has been readmitted to the hospital for evaluation. The patient also complained of recently vaginal bleeding and headache. At physical examination, she presented a slight mammillary retraction of the left breast with a palpable breast mass of $7 \times 3 \mathrm{~cm}$.

The work up showed a lesion in the mammogram, better evaluated in ultrasound (Fig.s 1 and 2). The patient also performed a breast magnetic resonance imaging (MRI) (Fig. 3) and a biopsy guided by ultrasound. The biopsy revealed an invasive carcinoma, G2, ER -, PR -, HER2 -, Ki67\% 25\%, CK19 +, E cadherin -, GCDFP15 (-),
CK8/18 (+), CDX2 (+). No carcinoma was found in the biopsy of axillary lymph node. The immunohistochemical characteristics, especially a CDX2+, suggests another origin for the breast mass, namely a gastrointestinal origin.

The patient completed staging with an abdomen and pelvic computed tomography (CT) scan (Fig. 4), that showed a gastric wall thickening and a bilateral ovarian mass that was further evaluated on ultrasound, and suggestive of a Krukenberg lesion (Fig. 5). An upper digestive endoscopy with biopsies was performed, showing macroscopic signs of gastritis and mucosal congestion (Fig. 6). The gastric biopsies revealed a signet ring cell carcinoma CKAE1/AE3(+) CDX2(+), HER2(-), GCDFP15(-).

During this work-up the patient presented a worsening of her clinical condition characterized by severe headache and diplopia. The etiological study of the new onset condition motivated the realization of a head and spine MRI that was suggestive of leptomeningeal dissemi-

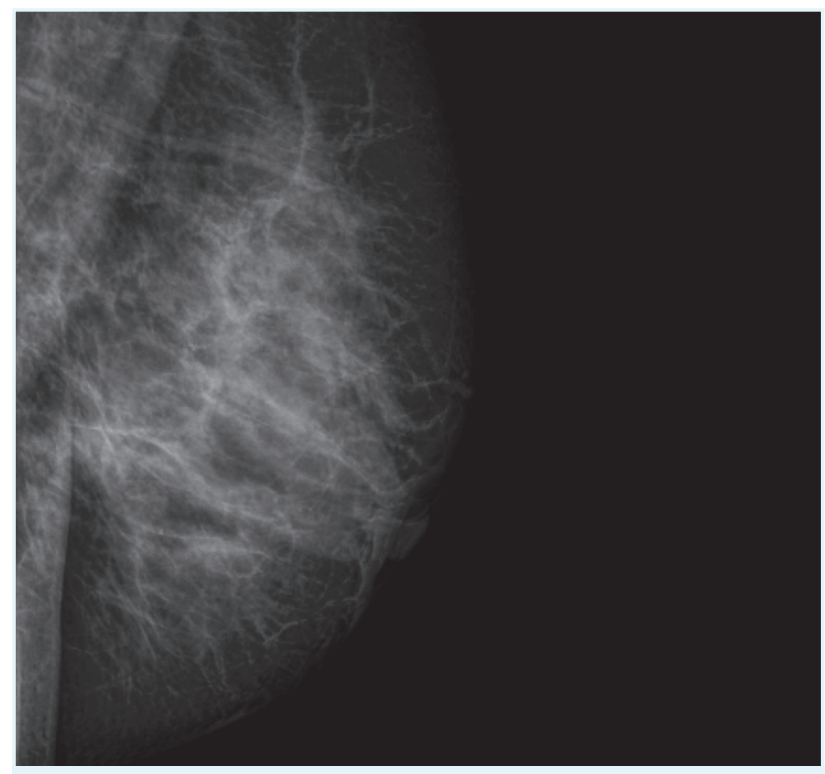

FIGURE 1. Left breast mammography, sagittal plane.

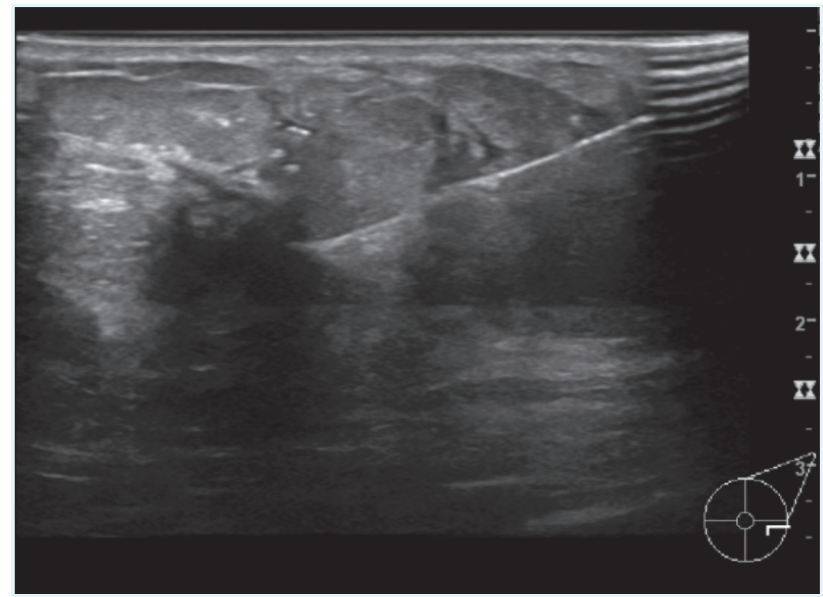

FIGURE 2. Breast UItrasound. 


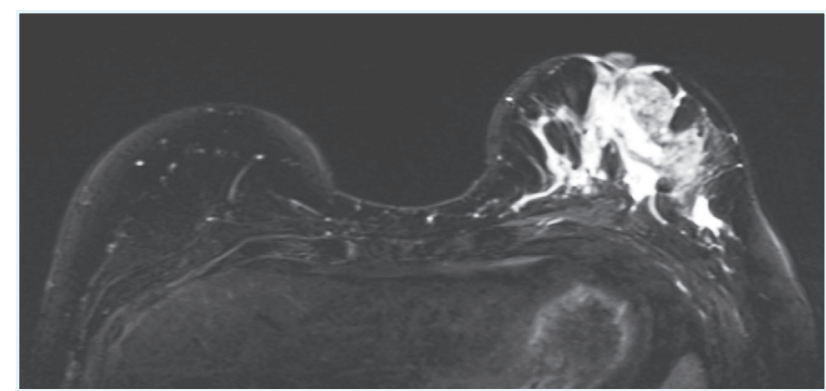

FIGURE 3. Breast MRI showing a large infiltrative lesion of the left breast.

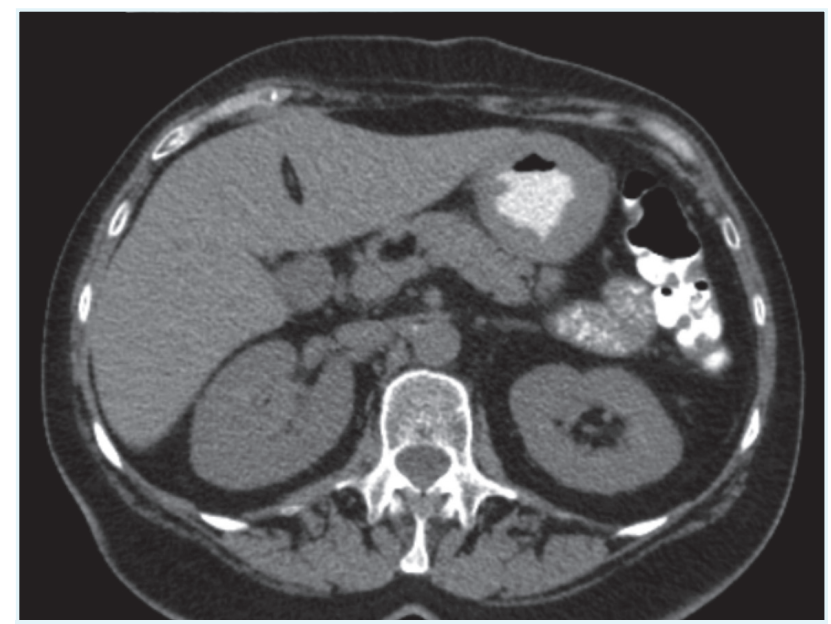

FIGURE 4. Gastric wall thickening.

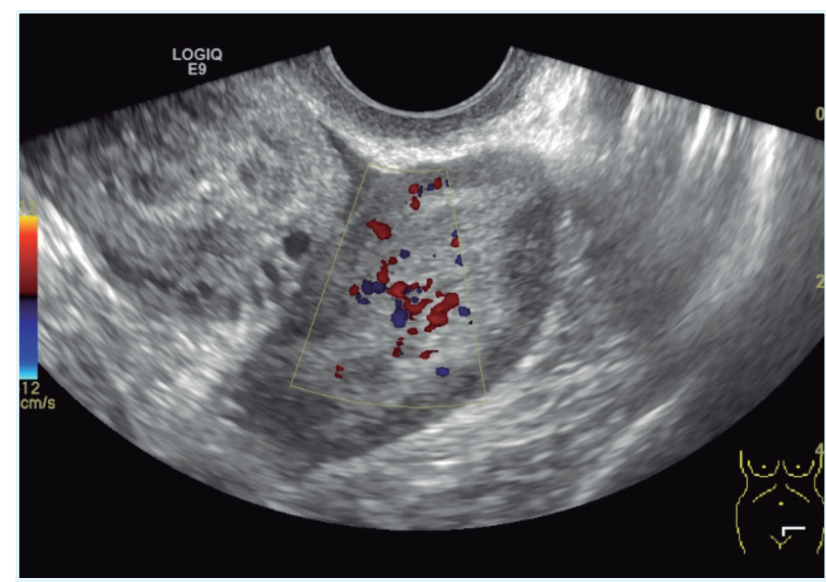

FIGURE 5. Ovarian mass in ultrasound.

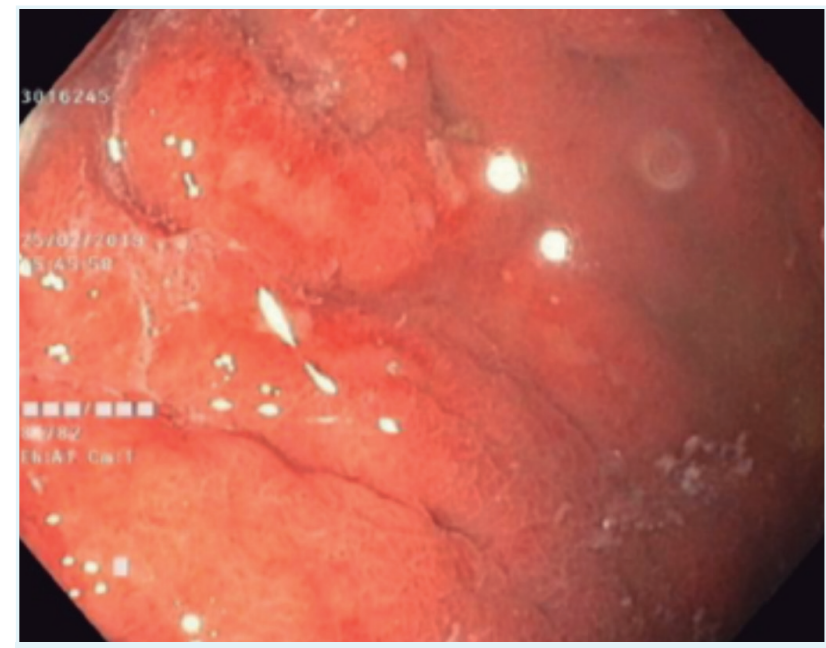

FIGURE 6. Gastritis. nation, further confirmed by lumbar puncture. At the multidisciplinary boarding meeting, she was proposed to a multimodal approach, starting with whole brain irradiation (WBRT) followed by chemotherapy with doublet based on taxane and platinum. The patient completed two cycles of chemotherapy with a gradual worsening of her general condition, that motivated the suspension of the targeted cancer treatment remaining only in supportive care. The overwhelming disease progression led to her death.

\section{DISCUSSION/CONCLUSION}

Metastasis of signet ring cell gastric carcinoma to the breast is extremely rare, with only approximately 40 cases reported according to the PubMed database until 2019.

Breast metastases from gastric carcinomas are associated with a poor prognosis, and the majority of patients die within 1 year. ${ }^{3,4}$ Patients who develop brain metastases tend to have even poor prognosis, with shorter overall survival. Besides BRCA mutations, several other mutations have been linked to this clinical picture, namely $\mathrm{CDH}-1$. Hereditary diffuse gastric cancer has been linked to this mutation and there is evidence for an increased risk for lobular breast to justify breast screening in females older than 35 years of age. Prophylactic mastectomy is still not fully supported by evidence. 5,6

\section{ETHICAL DISCLOSURES}

CONFLICTS OF INTEREST: The authors have no conflicts of interest to declare.

FINANCING SUPPORT: This work has not received any contribution, grant or scholarship.

CONFIDENTIALITY OF DATA: The authors declare that they have followed the protocols of their work center on the publication of data from patients.

PATIENT CONSENT: Consent for publication was obtained.

PROVENANCE AND PEER REVIEW: Not commissioned; externally peer reviewed.

\section{RESPONSABILIDADES ÉTICAS}

CONFLITOS DE INTERESSE: Os autores declaram a inexistência de conflitos de interesse na realização do presente trabalho.

FONTES DE FINANCIAMENTO: Não existiram fontes externas de financiamento para a realização deste artigo. 
CONFIDENCIALIDADE DOS DADOS: Os autores declaram ter seguido os protocolos da sua instituição acerca da publicação dos dados de doentes.

CONSENTIMENTO: Consentimento do doente para publicação obtido.

PROVENIÊNCIA E REVISÃO POR PARES: Não comissionado; revisão externa por pares.

\section{REFERENCES}

1. Lee SK, Kim WW, Kim SH, Hur SM, Kim S, Choi JH, et al. Characteristics of metastasis in the breast from extramammary malignancies. J Surg Oncol. 2010; 101:137-40. doi: 10.1002/jso.21453.

2. Areia M, Pimentel-Nunes P, Marcos-Pinto R, Dinis-Ribeiro M. Gastric cancer: an opportunity for prevention. Acta Med Port. 2013 ;26):627-9.

3. Ma Y, Liu W, Li J, Xu Y, Wang H. Gastric cancer with breast metastasis: Clinical features and prognostic factors. Oncol Lett. 2018;16:5565-74. doi: 10.3892/ ol.2018.9383.

4. Hong J, Kim Y, Cho J, Lim SW, Park SE, Kim HK, et al. Clinical features and prognosis of breast cancer with gastric metastasis. Oncol Lett. 2019;17:1833-41. doi: 10.3892/ol.2018.9754.

5. Blair V, Martin I, Shaw D, Winship I, Kerr D, Arnold J, et al. Hereditary Diffuse Gastric Cancer: Diagnosis and Management Clin Gastroenterol Hepatol. 2006;4:262-75. doi: 10.1016/j.cgh.2005.12.003.

6. Dulskas A, Al Bandar M, Choi YY, Shin SJ, Beom SH, Son T, et al. A case of gastric cancer metastasis to the breast in a female with BRCA2 germline mutation and literature review. Acta Chir Belg. 2019;119:5963. doi: 10.1080/00015458.2017.1411554. 